OPEN ACCESS

Edited by:

Zhi-jun Dai,

East China Normal University, China

Reviewed by:

Wenhong Pang,

East China Normal University, China

Mei Xuefei,

East China Normal University, China

*Correspondence:

Cong Mai Van

cong.m.v@tlu.edu.vn

Specialty section: This article was submitted to Coastal Ocean Processes, a section of the journal

Frontiers in Marine Science

Received: 10 August 2021

Accepted: 13 September 2021

Published: 22 October 2021

Citation:

Mai Van C, Ngo A, Mai T and Dao HT (2021) Bamboo Fences as a

Nature-Based Measure for Coastal

Wetland Protection in Vietnam.

Front. Mar. Sci. 8:756597

doi: 10.3389/fmars.2021.756597

\section{Bamboo Fences as a Nature-Based Measure for Coastal Wetland Protection in Vietnam}

\author{
Cong Mai Van ${ }^{1 *}$, Anh $\mathrm{Ngo}^{1}$, Tri Mai ${ }^{2}$ and H. T. Dao ${ }^{3}$ \\ ${ }^{1}$ Faculty of Civil Engineering, Thuyloi University, Hanoi, Vietnam, ${ }^{2}$ Faculty of Coastal and Offshore Engineering, Hanoi \\ University of Civil Engineering, Hanoi, Vietnam, ${ }^{3}$ Faculty of Marine Science and Island, Hanoi University of Natural Resources \\ and Environment, Hanoi, Vietnam
}

Climate change has induced sea-level rise and a high intensity of storms, which create high nearshore waves. These caused severe mangrove degradation and erosion along the coastal wetland areas in the Mekong Delta in Vietnam. Mangroves in the coastal wetland foreshore can withstand only some certain design storm waves and grow under several certain submerged conditions. Therefore, reducing waves and shallowing wetland elevation for recovering mangroves and protecting them in an early birth state is important. Bamboo or melaleuca fences have been used as a nature-based solution to reduce waves and currents approaching the shore for these above purposes along Vietnamese Mekong deltaic coasts. This paper investigates wave transmission through the bamboo fence system and assesses its effectiveness in protecting the mangroves. Waves were simultaneously measured at two locations for comparison: in front of and behind the fences. The result shows that the wave reduction by the fences is considerable, and sedimentation occurs rapidly in the shelter areas behind the fences, which is highly favorable for the recovery and growth of mangroves. Next, the empirical formulae have been proposed for relationships between the wave transmission coefficient of the fence and the dimensionless wave-structures parameters, such as the relative water depth, the wave steepness, and the fence freeboard. The findings create a basic technical reference for designing a naturally friendly-based solution by using bamboo and/or wooden fences in coastal protection generally and protecting mangroves specifically. The outcome of the research contributes to narrowing an existing gap in Vietnamese design guidelines for coastal wetland protection and also facilitates the use of locally available eco-friendly materials for coastal management along the Vietnamese Mekong delta coasts.

Keywords: wave transmission, wooden fence, coastal protection, Mekong delta coast, nature based solution, bamboo fence

\section{INTRODUCTION}

Coastal regions are historically the most densely populated areas globally, which benefit from the open ocean and provide inputs for economic development, such as navigation, coastal industries, tourism, and recreation. However, coastal regions are increasingly threatened by the sea-level rise and coastal hazards, such as intense storm surges and hurricanes. Church and White (2006) stated that the sea level might rise about $19 \mathrm{~cm}$ in the past century and estimate to rise at least $28 \mathrm{~cm}$ to 
$34 \mathrm{~cm}$ by 2100 . Along with the sea-level rise, the alert from increased coastal hazards is noticeable, with more than $66 \%$ of storm and hurricane events happening in the $21^{\text {st }}$ century (ICCP, 2007). Most of the low-lying land is vulnerable if these estimations are taken seriously. To protect valuable lands, hard solutions to prevent coastlines sensitive to the sea-level rise become more prevalent. The implementation of coastal protection, e.g., breakwaters, groins, revetments, and sea dikes (Schoonees et al., 2019), brings a certain safety level for the inland from flooding incidents during storm surges or increased sedimentation to a particular area.

The hard solution is the action of human intervention that always interrupts the balance of natural coasts. In principle, the presence of permanent coastal structures changes the hydrodynamics of the coasts, including wave regimes and flow dynamics (Dugan et al., 2011). Consequently, the gradients in sediment transport and depositional processes will be changed, leading to an imbalance of sediment and morphology changes, including acceleration at the updrift side and erosion at the downdrift side of the structure (Schoonees et al., 2019).

Mangroves, known as the natural coastal defenses, are the coastal vegetation that usually lives in the intertidal areas, including along shorelines, rivers, and estuaries (Duke and Schmitt, 2015). Mangroves mostly grow in tropical or subtropical regions where the warm temperature is designed for them to withstand (Alongi, 2008, 2009). Mangroves can be easily recognized by the complex systems of their body, e.g., roots, stems, and canopies. Unfortunately, mangroves are extremely sensitive to surrounding environments, such as economic activities and especially, the presence of coastal structures. The sensitivity of mangroves becomes more significant than before, especially in the era of the sea-level rise, making mangroves as the most vulnerable ecosystems in the world. Moreover, the increase in fish farming and aquaculture resulting in an estimation of about $2 \%$ of mangroves loss annually, and about $40 \%$ of mangrove forests lost in the next two decades (Gilman et al., 2008). Furthermore, the coastal structures, such as seawall, sea dikes, or revetments, are recognized as a fixed boundary between mangrove forests and the intertidal land, which become an obstruction for a natural retreat of the mangroves themselves under a sea-level-rise situation.

In the Mekong deltaic coast, the reduction of mangrove forests has been even more serious/severe since the combination of sea dikes and aquaculture, such as shrimp ponds, is presented along the coastal area. From 2009 to 2010, severe erosion occurred along about $30 \mathrm{~km}$ of coastline, resulting in about $8 \mathrm{~km}$ of eroded earthen dikes (Duke et al., 2010). Moreover, according to a report of SIWRR (2019), about $80 \mathrm{~km}$ of the total $744 \mathrm{~km}$ of the Mekong deltaic coastline was protected by sea dikes and revetments to prevent erosion and flooding. As a result, nearly 50\% of mangrove forests vanished in the past decade (Christensen et al., 2008; Joffre and Schmitt, 2010; Nguyen et al., 2013).

There are many studies to find solutions for protecting the coastline from erosion due to waves and currents. These solutions could be hard-structure solutions (U. S. Army Corps of Engineers, 1992; Van Rijn, 2013) and eco-friendly structure measures (Hegde, 2010; MFF, 2010; Albers et al., 2013; Wetland International, 2014). Nowadays, soft solutions that are friendly with the environment have been prioritized over hard solutions. Soft solutions are also more convenient and less cost-effective than hard structures, especially to apply in coastal areas formed by silt and wetland because of an unstable foundation. One of the most eco-friendly and sustainable structure solutions, which have been developed and expanded, is mangrove planting. The mangrove belt systems used for reducing waves and currents to protect coastlines and sea dykes were investigated and presented in Mazda et al. (1997). In severely eroded and affected by large waves and high-tides coastal areas, mangroves cannot grow due to the inundation time. Therefore, reducing waves and rising wetland elevation for planting mangroves during the planting period is very necessary. Moreover, wooden (bamboo or melaleuca) fences have been used to reduce wave energy to shore and to increase sedimentation along coastlines in Vietnam (Reeve and Fleminget, 2004; Albers, 2011; Chu and Brown, 2012; Dao et al., 2018).

Additionally, Dao et al. (2020) carried out experiments to obtain the resistance of the wooden fence that mimicked the one in the field. In this study, the fence samples with porosity varying from 62 to $90 \%$ in both a model- and a full-scale set-up in inhomogeneous and staggered arrangements were investigated by using the hydraulic pressure gradient method. The flow resistance was determined by measuring the hydraulic gradient under stationary flows. The experimental results demonstrated that the bulk drag coefficient has a strongly dependent relationship with the Reynolds number. This coefficient increases quickly with the increase of the Reynolds number and becomes stable at the value exceeding 1,000. The finding from this study then was applied in another study in Dao et al. (2021). In the latter study, the bulk drag coefficient is the main parameter for controlling wave-fence interaction in the numerical model, SWASH. The numerical results determined the strong dependence of wave transmission coefficient on the wooden fence thickness. However, only wave-fence interaction was investigated, while the determination of sediment transport through wooden fences has been developed.

This paper analyzes the observed data from a practical model for mangrove planting to understand the efficiencies of a wooden fence on waves reduction and transmission at the coastal area in Nha Mat ward, Bac Lieu city, Vietnam. Wave data in the front and at the rear of the fence have been measured (Figure 1). In addition, sedimentation in the researched area has been observed and will be analyzed and presented in this paper.

\section{METHODOLOGY}

A prototype experimental model with a scale of 1:1 was built in the coastal area in Nha Mat ward, Bac Lieu City (Figure 1) in February 2016. The longitude and latitude of the tested model were $105^{\circ} 44^{\prime} 46.86^{\prime \prime} \mathrm{E}$ and $9^{\circ} 12^{\prime} 10.98^{\prime \prime} \mathrm{N}$, respectively. The bamboo fence was composed of three main rows of bamboo poles with a diameter of $0.06 \mathrm{~m}$ and a height of $1.6 \mathrm{~m}$ and an additional row with a height of $0.9 \mathrm{~m}$ as a frame. The spacing between rows of the frame is $0.4 \mathrm{~m}$ and filled with bundles of bamboo. Thus, the total working width of the fence is 0.8 and is $1.2 \mathrm{~m}$ with the additional row. The detailed structure of 

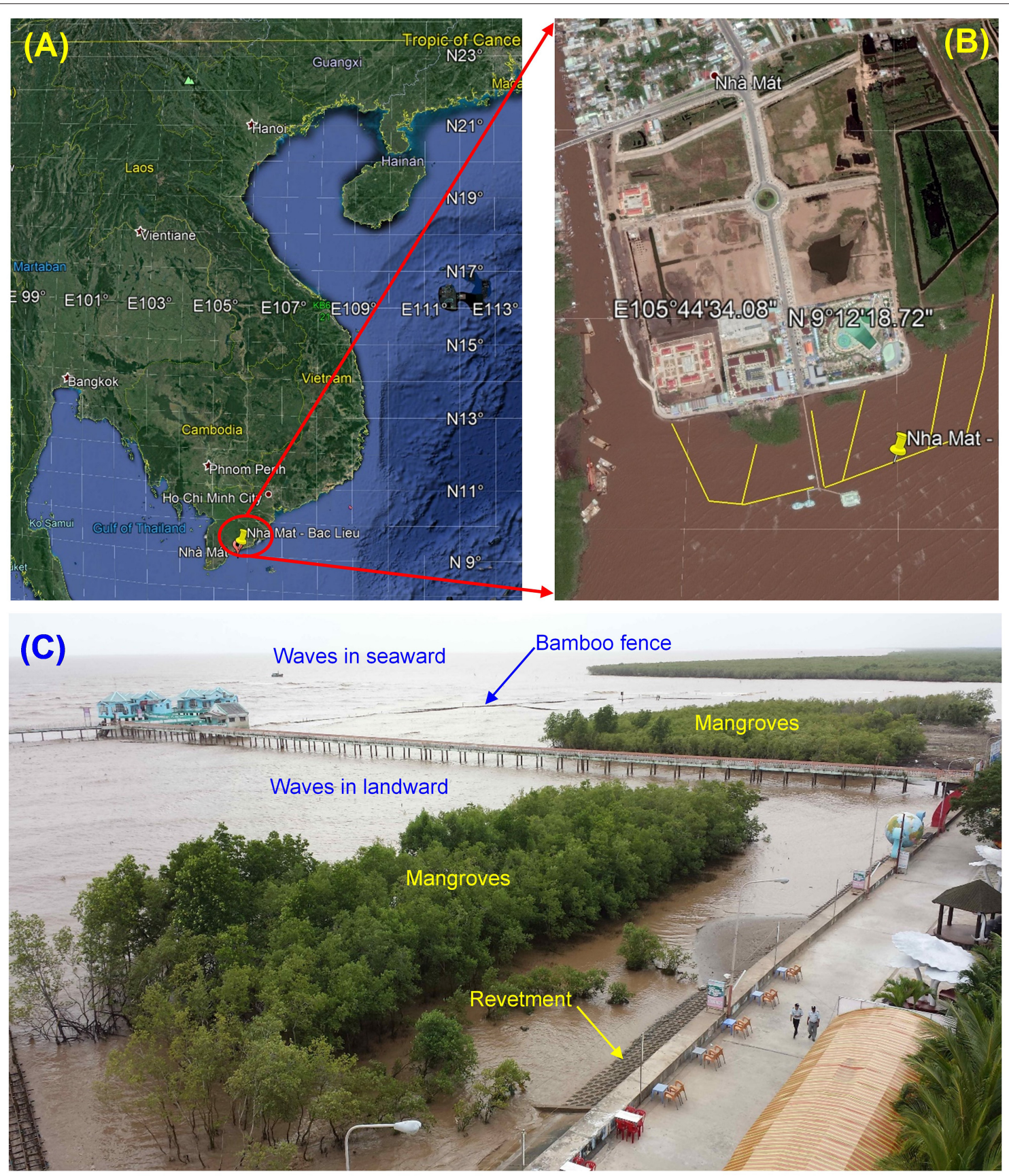

FIGURE 1 | The study area in Nha Mat ward, Bac Lieu City in Vietnam: (A) Vietnamese coast; (B) Nha Mat coast; (C) A photo taken at Nha Mat coast.

the fence is shown in Figure 2, along with a photo taken from the field.

Wave gauges TGR-1050-P and TWR-2050, which are operating based on the water column pressure method, were used to synchronistically measure waves in the upstream and downstream of the fence in this research. These wave gauges were tested in the laboratory under freshwater conditions before the measurements in the field. The details of this experiment were introduced by Mai et al. (2018). In addition, the influence of sampling frequency on wave characteristics has been analyzed and detailed in a study by Ellis and Sherman (2005) and resulted in the significant wave height $H_{\mathrm{s}}$ and peak wave period $T_{\mathrm{p}}$ at 1. $\mathrm{Hz}$ as same as at $50 \mathrm{~Hz}$ frequency for wave measurements at Galveston, based on wave spectral analysis. However, at Huntington Beach, the wave height and the wave period from $1 \mathrm{~Hz}$ sampling frequency data resulted in varying percentages from 0.3 to $2.5 \%$, compared with the results at $50 \mathrm{~Hz}$ frequency. Therefore, Ellis and Sherman (2005) recommend tuning the 

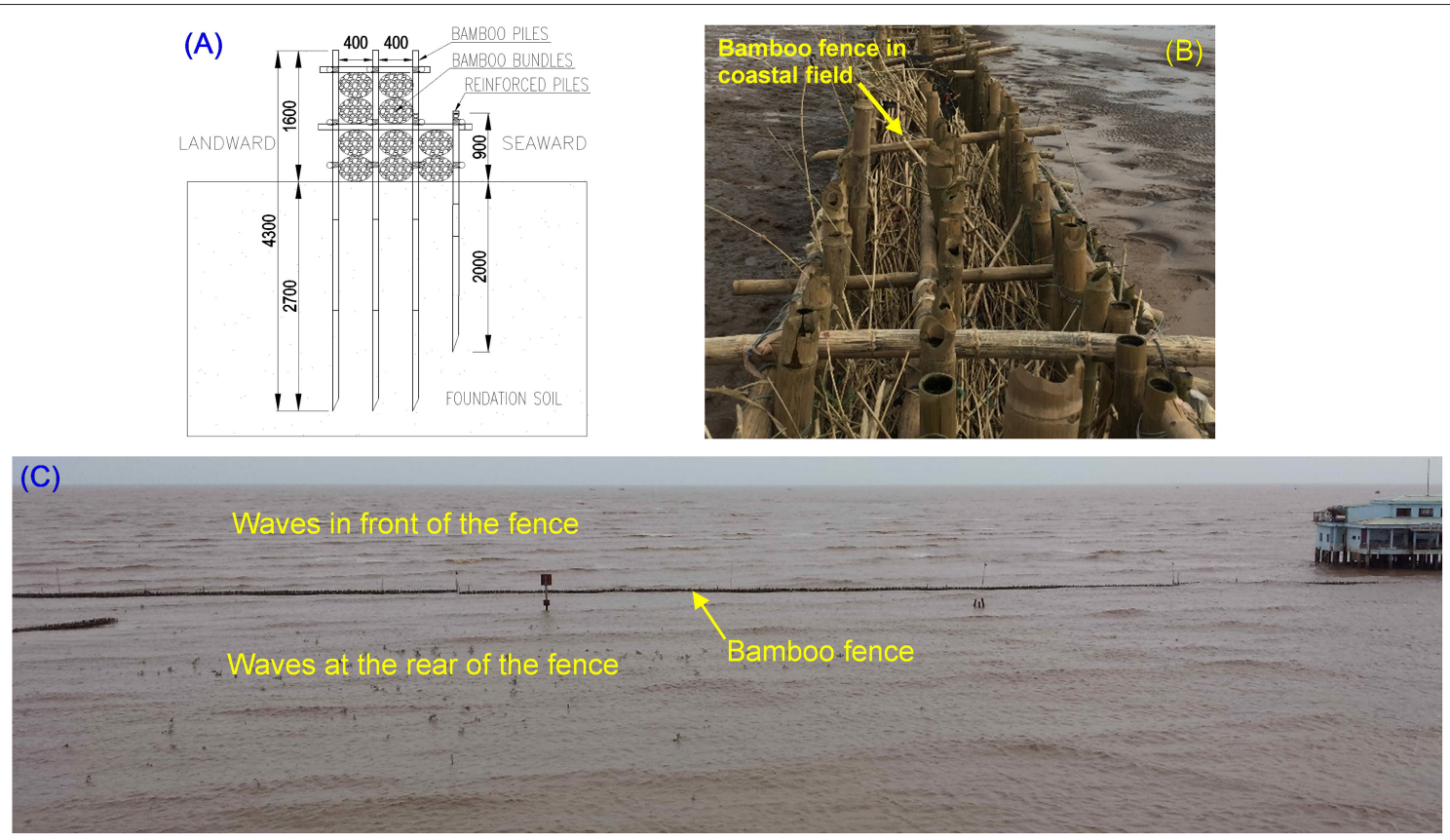

FIGURE 2 | Cross-section of bamboo fences (A), bamboo fences at the coastal site (B), and incident and transmitted waves at the coastal site (C).

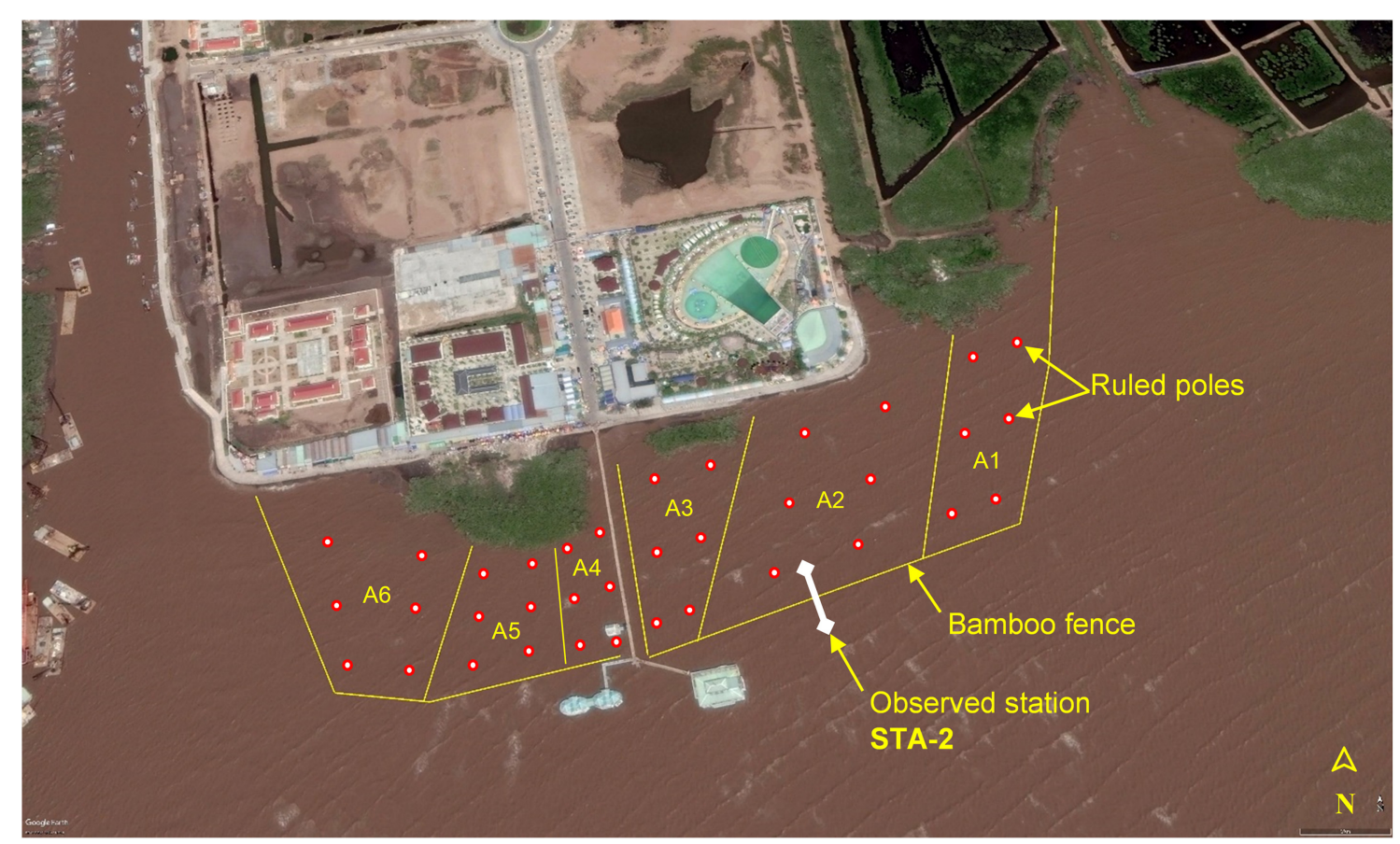

FIGURE 3 | Locations of the wave observing station (STA-2) and the sedimentation areas A1-A6 at the site.

measurement frequencies $\geq 0.5 \mathrm{~Hz}$ to measure field waves. Thus, the sampling frequency of data in this research was initially selected as $1 \mathrm{~Hz}$. This study analyzes and presents the 2016 southwest and northeast monsoons results at the observed station
STA-2 (Figure 3). The distance between two measuring devices is $25 \mathrm{~m}$ that is equivalent to one wavelength.

The Nha Mat coast is characterized by a very gentle bathymetry with an average slope of about $1 / 500$ at the observed 
TABLE 1 | Sediment grain size at the Nha Mat coast.

\begin{tabular}{|c|c|c|c|c|c|c|c|}
\hline Sediment grain size (mm) & $0.5-0.25$ & $0.25-0.1$ & $0.1-0.063$ & 0.063-0.02 & $0.02-0.006$ & $0.006-0.002$ & $<0.002$ \\
\hline Content (\%) & 0 & 3.6 & 88.52 & 3.88 & 2.16 & 1.84 & 0 \\
\hline
\end{tabular}
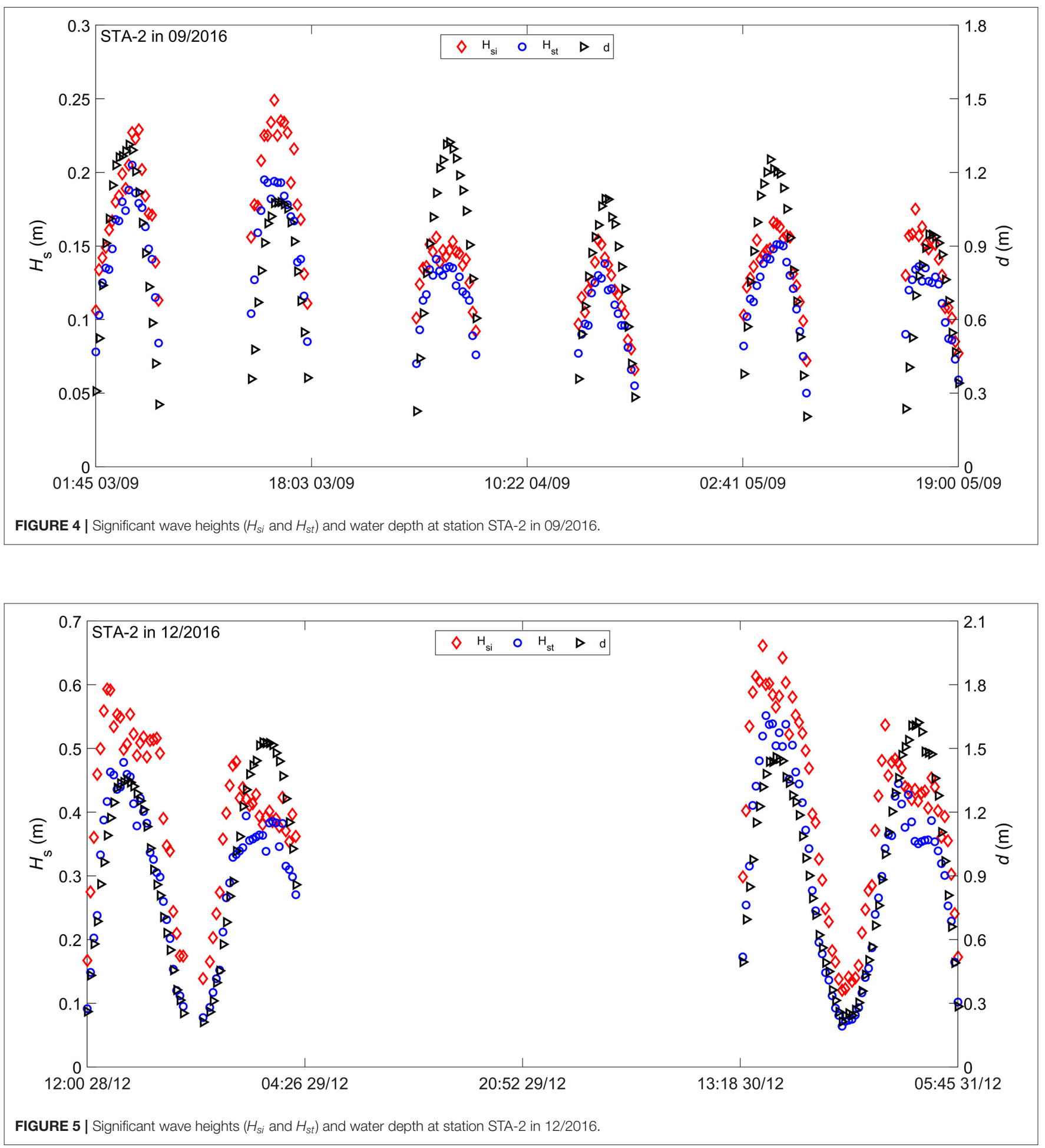


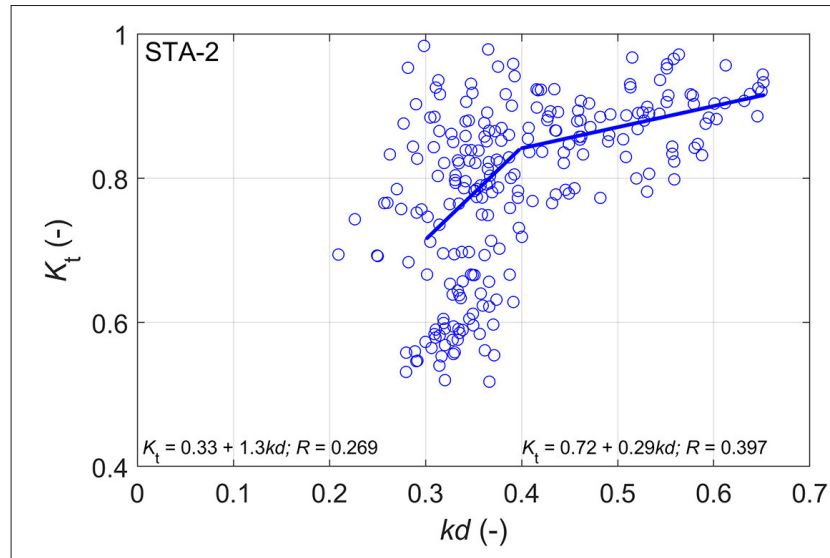

FIGURE 6 | The relationship between the wave transmission coefficient $K_{t}$ and the relative water depth $k d$.

time in March 2016. The semidiurnal tide is the typical water level variation at the Nha Mat coast. The tidal range in the researched area varies from 1 to $1.6 \mathrm{~m}$. Currents at this site were observed during the experiment and varied from 0.4 to $0.6 \mathrm{~m} / \mathrm{s}$. Sediment grain sizes at the Nha Mat coast were also observed in March 2016, as shown in Table 1.

Sedimentation in the study area has been observed in six zones by installing six ruled poles in each zone to read the wetland surface elevation every 20 days (Figure 3).

\section{RESULTS AND DISCUSSIONS}

The result of wave measurements at the front and the rear of the bamboo fence and the depth of water is presented in Figures 4, 5 at station STA-2 in 09/2016 and 12/2016, respectively. In Figures 4, 5, $H_{\mathrm{si}}$ is the significant incident wave height (the red diamond symbol); $H_{\text {st }}$ is the significant transmitted wave height (the blue circle symbol), and $d$ is the water depth at the location of the measuring station (the black triangle symbol). The data were filtered out with conditions that waves were measured in water depth $d \geq 0.2 \mathrm{~m}$ to remove the affected data due to too-shallow water depth. Preliminary assessments show that the significant incident wave height has been significantly reduced by the bamboo fence (Figures 4, 5).

The transmission coefficient is determined according to Equation (1):

$$
K_{t}=\frac{H_{s t}}{H_{s i}}
$$

where: $H_{\mathrm{si}}$ is the significant incident wave height, and $H_{\mathrm{st}}$ is the significant transmitted wave height.

The wave transmission coefficient of the fence in 2016 in the study area is presented in Figures 6-8. The relationship between the wave transmission coefficient and nondimensional parameters, such as the relative water depth $k d$, wave steepness $k H_{\mathrm{si}}$, and the relative freeboard $R_{\mathrm{c}} / H_{\mathrm{si}}$ where $k$ is the incident wave number, and $R_{\mathrm{c}}$ is the freeboard of the fence. The freeboard

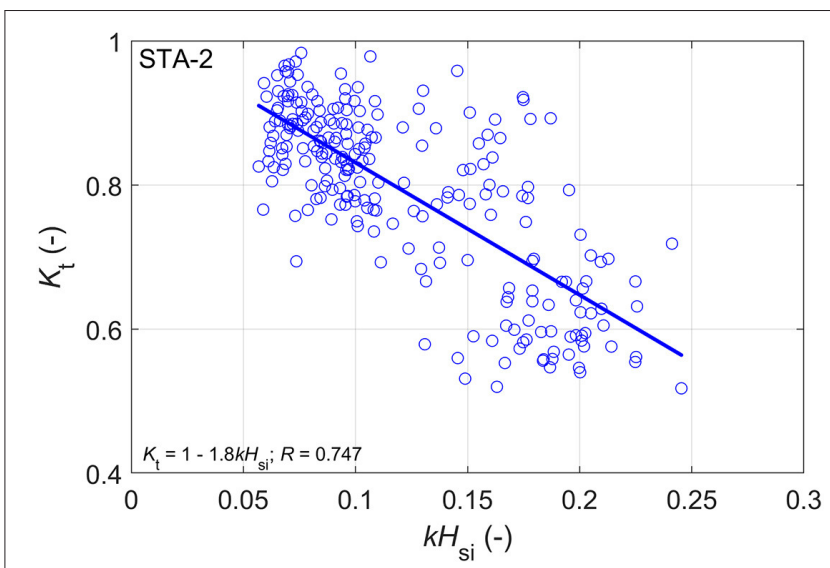

FIGURE 7 | The relationship between the wave transmission coefficient $K_{t}$ and the wave steepness $\mathrm{KH}_{\text {si }}$.

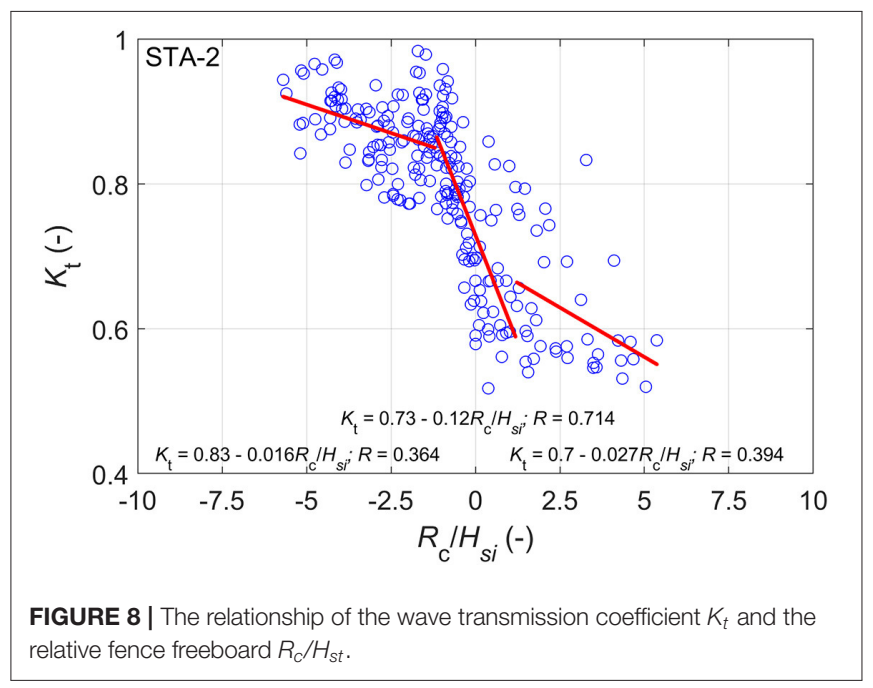

TABLE 2 | Empirical coefficients of the Equation (5).

\begin{tabular}{lcc}
\hline $\boldsymbol{a}$ & $\boldsymbol{b}$ & Conditions \\
\hline-0.016 & 0.83 & $R_{\mathrm{c}} / H_{\mathrm{si}}<-1.2$ \\
-0.12 & 0.73 & $-1.2 \leq R_{\mathrm{C}} / H_{\mathrm{si}} \leq 1.2$ \\
-0.027 & 0.70 & $R_{\mathrm{C}} / H_{\mathrm{si}}>1.2$ \\
\hline
\end{tabular}

of the fence $\left(R_{\mathrm{c}}\right)$ is the distance between the crest level of the fence $\left(Z_{\mathrm{f}}\right)$ and the water level $(W L)$, expressed as $R_{\mathrm{c}}=Z_{\mathrm{f}}-W L$. Thus, $R_{\mathrm{c}}$ is positive if the crest level of the fence is higher than the water level. In contrast, $R_{\mathrm{c}}$ is negative if the crest level of the fence is lower than the water level; this means that the fence is submerged in water for this case.

Figure 6 shows the relationship between wave transmission coefficient and the relative water depth $(k d)$. It can be seen that the wave transmission coefficient $K_{\mathrm{t}}$ increases with the increase of the relative water depth $(k d)$. Therefore, if the water depth increases, the wave height reduction due to the fence decreases. 


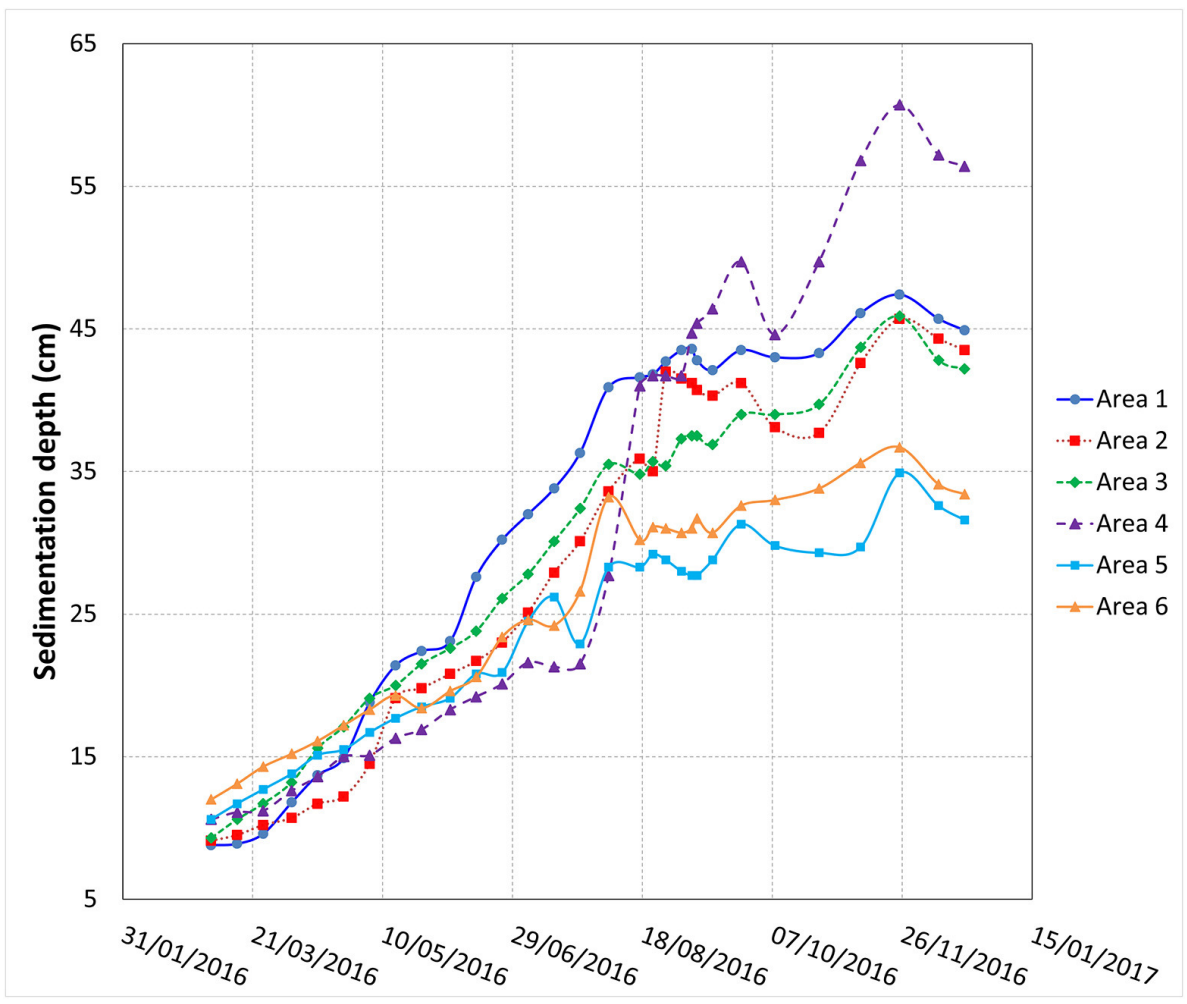

FIGURE 9 | Sediment accumulation in the study area after the presence of bamboo fences.

That is reasonable due to the fact that, in a higher water depth (same as the water level), the waves could be easy to transmit through the fence. The empirical relationship between the wave transmission coefficient $K_{\mathrm{t}}$ and the relative water depth $(k d)$ is proposed as Equation (2) and (3):

$$
\begin{aligned}
& K_{t}=0.33+1.3 k d \text { if } k d<0.4 \\
& K_{t}=0.72+0.29 k d \text { if } k d \geq 0.4
\end{aligned}
$$

The relationship between the wave transmission coefficient and the wave steepness $k H_{\mathrm{si}}$ is shown in Figure 7. In contrast to the relationship of $K_{\mathrm{t}}$ and $k d$ presented in Figures 6, 7 shows that, as the wave steepness $\left(k H_{\text {si }}\right)$ is increasing, the wave transmission coefficient decreases. The proposed empirical formula for $K_{\mathrm{t}}$ and $k H_{\text {si }}$ is presented in Equation (4):

$$
K_{t}=1-1.8 k H_{s i}
$$

Figure 8 presents a relationship between the wave transmission coefficient $K_{\mathrm{t}}$ and the relative fence freeboard $R_{\mathrm{c}} / H_{\mathrm{si}}$, showing the dependence of the wave transmission coefficient on the freeboard. It is shown that the relative freeboard $R_{\mathrm{c}} / H_{\mathrm{si}}$ varies from -5.7 to +5.4 for the fence used at station STA- 2 according to the measurements. The results also show that the wave transmission coefficient decreases with the increase of the relative fence freeboard $R_{\mathrm{c}} / H_{\mathrm{si}}$. This result is similar to previous studies done by Albers et al. (2013) and Schmitt et al. (2013) for the fence system built in the Soc Trang coast, Vietnam. In addition, the relative freeboard of the fence becomes zero, i.e., $R_{\mathrm{c}} / H_{\mathrm{si}}=0$; the wave transmission coefficient is still relatively high, $K_{\mathrm{t}}=0.73$.

The relationship between the wave transmission coefficient $\left(K_{\mathrm{t}}\right)$ and the relative fence freeboard $R_{\mathrm{c}} / H_{\mathrm{si}}$ is determined based on the best fit line in Figure 8. This relationship is expressed as Equation (5):

$$
K_{t}=a \frac{R_{c}}{H_{s i}}+b
$$

where $a$ and $b$ are the empirical coefficients obtained from the analysis of the data in this study, and their values are presented in

\section{Table 2.}

The observed sedimentation depths are presented in Figure 9. It is shown that the sedimentation depth has been increased about 30-60 cm after 10 months (from March 5, 2016, to December 20, 2016) from the time the bamboo fences were installed in the study area. Consequently, the new wetland surface could be used to start planting young mangroves. Note that sediment transport can be closely linked to wave actions, including short and long waves, especially long waves play a vital role as the controlling factor in the net sediment transport (Baldock et al., 2010). Additionally, this net transport relatively links to the odd moment $<u|u|^{2}>$ (Bosboom and Stive, 2012), 
where $u$ is the time-averaged velocity, insisting a high-frequency oscillatory motion of short waves and low-frequency motion at wave-group scale (long waves). The term $u^{2}$ can be related to the sediment concentration stirred up by the oscillatory wave motion and is relatively proportional to the wave height in the shallow water. As shown in Figure 8, waves reduce about $40 \%$ of their heights at relatively shallow depths, resulting in estimation for the remaining long waves energy propagated through the fences. Furthermore, the incident wave and wave group related to long-wave propagation could correspond to sediment concentrations in the shoaling wave conditions (Pang et al., 2020). Because the measured sedimentation level behind the fence shows an increasing trend, the sediment induced by long-wave motions might contribute a vital role in the increase of the sedimentation level.

\section{CONCLUSIONS AND RECOMMENDATION}

The incident and transmitted waves during the southwest and northeast monsoons in 2016 in Nha Mat have been analyzed and presented in this paper. The measured wave data were filtered with the condition that those waves were measured in the water depth $d \geq 0.2 \mathrm{~m}$. This paper also presents the results including the relationships between the wave transmission coefficient $\left(K_{t}\right)$ and the relative water depth $(k d)$, the wave steepness $\left(k H_{\mathrm{si}}\right)$, and the relative fence freeboard $\left(R_{\mathrm{c}} / H_{\mathrm{si}}\right)$. Furthermore, sedimentation in the wetland area was observed and presented in this study.

Based on the results of data analysis, several conclusions are given as follows: (i) the wave transmission coefficient $\left(K_{\mathrm{t}}\right)$ decreases as increasing the wave steepness $\left(k H_{\text {si }}\right)$, but in contrast, the wave transmission coefficient $K_{\mathrm{t}}$ is increasing as the relative water depth $(k d)$ increases; (ii) As the relative fence freeboard $R_{\mathrm{c}} / H_{\mathrm{si}}$ increases, the wave transmission coefficient decreases and reaches $K_{\mathrm{t}}=0.73$ when $R_{\mathrm{c}} / H_{\mathrm{si}}=0$ (the crest fence level at the water level); (iii) Preliminarily formulation of the empirical

\section{REFERENCES}

Albers, T. (2011). "Design of Breakwaters." Vietnam: CZM Soc Trang. pp. 61.

Albers, T., San, D. C., and Schmitt, K. (2013). "Shoreline Management Guidelines: Coastal Protection in the Lower Mekong Delta", Deutsche Gesellschaft für Internationale Zusammenarbeit (GIZ) GmbH, pp. 1-124.

Alongi, D. (2009). The energetics of mangrove forests. Springer Science \& Business Media.

Alongi, D. M. (2008). Mangrove forests: resilience, protection from tsunamis, and responses to global climate change. Estuar. Coast. Shelf Sci.76, 1-13. doi: 10.1016/j.ecss.2007.0 8.024

Baldock, T.E.; Manoonvoravong, P., and Pham, K.S., (2010). Sediment transport and beach morphodynamics induced by free long waves, bound long waves and wave groups. Coastal Engineering. 57, 898-916. doi: 10.1016/j.coastaleng.2010.05.006

Bosboom, J., and Stive, M. J. F. (2012). Coastal Dynamics I. Lectures Notes CIE4305. Delft, The Netherlands: VSSD pp. 584.

Christensen, S. M., Tarp, P., and Hjorts, $\varnothing$, C. N. (2008). Mangrove forest management planning in coastal buffer and conservation zones, Vietnam: A multimethodological approach incorporating multiple stakeholders. Ocean Coast. Manag. 51, 712-726. doi: 10.1016/j.ocecoaman.2008.06.014 formulae for calculating the wave transmission coefficient $K_{\mathrm{t}}$ in terms of the relative water depth $k d$, the wave steepness $k H_{\mathrm{si}}$, and the relative fence freeboard $R_{\mathrm{c}} / H_{\mathrm{si}}$; (iv) Sedimentation depth could be increased up to $0.60 \mathrm{~m}$, which is significant for planting new mangrove belt for eco-friendly coastal protection.

Findings from this research create a technical basic reference for the design of a nature-based solution by using bamboo and/or wooden fences for coastal protections, which currently, is a gap in existing Vietnamese design guidelines. This facilitates, also, the use of the local available eco-friendly materials for coastal protection and management along the Vietnamese Mekong delta coasts instead of applying many concrete structures presently.

\section{DATA AVAILABILITY STATEMENT}

The raw data supporting the conclusions of this article will be made available by the authors, without undue reservation.

\section{AUTHOR CONTRIBUTIONS}

CM: conceptualization, methodology, formal analysis, visualization, and writing-original draft. AN: conceptualization and writing-review and editing. TM: conceptualization, investigation, and writing - review and editing. HD: writingreview and editing. All authors contributed to the article and approved the submitted version.

\section{ACKNOWLEDGMENTS}

The authors gratefully acknowledge the support from the Ministry of Education and Training in Vietnam (project code: B2020-XDA-02) and International Science and Technology Cooperation Foundation Projects of Shanghai (19230742700) for this research.
Chu, V. C., and Brown, S. (2012). Phục hôi vùng ven biên và rùng ngâp măn băng hàng rào cù tràm. Deutsche Gesellschaft für Internationale Zusammenarbeit (GIZ) $\mathrm{GmbH}, 26 \mathrm{tr}$.

Church, J. A., and White, N. J. (2006). A 20th century acceleration in global sea-level rise. Geophys. Res. Lett. 33L01602. doi: 10.1029/2005GL024826

Dao, H. T., Hofland, B., Stive, M. J. F., and Mai, T. (2020). Experimental Assessment of the Flow Resistance of Coastal Wooden Fences. Water. 12, 1910. doi: $10.3390 /$ w12071910

Dao, H. T., Hofland, B., Suzuki, T., Stive, M. J. F., Mai, T., and Tuan, L. X. (2021). Numerical and small-scale physical modelling of wave transmission by wooden fences. J. Coastal Hydraulic Structures. 1, 1-21. doi: 10.48438/jchs.2021.0004

Dao, T., Stive, M. J. F., Hofland, B., and Mai, T. (2018). Wave Damping due to Wooden Fences along Mangrove Coasts. J. Coastal Research. 34(6), 1317-1327. doi: 10.2112/JCOASTRES-D-18-00015.1

Dugan, J. E., Airoldi, L., Chapman, M. G., Walker, S. J., Schlacher, T., Wolanski, E., et al. (2011). Estuarine and coastal structures: environmental effects, a focus on shore and nearshore structures. Treatise Estuar. Coast. Sci. 8, 17-41. doi: 10.1016/B978-0-12-374711-2.00802-0

Duke, N., Wilson, N., Mackenzie, J., Nguyen, H. H., and Puller, D. (2010). Assessment of Mangrove Forests, shoreline condition and feasibility for REDD in Kien Giang Province, Vietnam. Dtsch. Gesellschaft für Tech. Zusammenarbeit. pp. 1-128. 
Duke, N. C., and Schmitt, K. (2015). Mangroves: unusual forests at the seas edge. Trop. For. handbook. Pancel L., Kohl M, editors. Springer. pp. 24. doi: 10.1007/978-3-642-41554-8_129-1

Ellis, J. T., and Sherman, D. J. (2005). Effects of sampling frequency on wave characterization. Zeitschrift fur Geomorphologie, Supplementband, Coasts Under StressII SV141. Pp. 183-195.

Gilman, E. L., Ellison, J., Duke, N. C., and Field, C. (2008). Threats to mangroves from climate change and adaptation options: a review. Aquat. Bot. 89, 237-250. doi: 10.1016/j.aquabot.2007.12.009

Hegde, A. V. (2010). Coastal erosion and mitigation methods - global state of art. Indian J Mar Sci. 39, 521-530. Available online at: http://nopr.niscair.res.in/ handle/123456789/10799

IPCC (2007). Climate Change 2007: Synthesis Report. Contribution of Working Groups I, II and III to the Fourth Assessment Report of the Intergovernmental Panel on Climate Change, eds Core Writing Team, R. K. Pachauri, and A. Reisinger. Geneva: IPCC, 104. Available online at: https://www.ipcc.ch/report/ ar4/syr/

Joffre, O. M., and Schmitt, K. (2010). Community livelihood and patterns of natural resources uses in the shrimp-farm impacted Mekong Delta. Aquac. Res. 41, 1855-1866. doi: 10.1111/j.1365-2109.2010.02588.x

Mai, C. T., Hoang, T. L. G., Mai, T. L., and Le, T. T. (2018). Hiêu qua giam sóng cua các loại tuòng mêm xây dụng tại bò biên Nhà Mát, tinh Bạc Liêu.Tạp chí Tài nguyên nuóc, Sô 01, 01/2018 (Vietnamese; Abstract in English).

Mazda, Y., Magi, M., Kogo, M., Hong, P. N. (1997). Mangroves as a coastal protection from waves in the Tong King delta, Vietnam. Mangroves and Salt Marshes. 1, 127. doi: 10.1023/A:1009928003700

MFF (2010). Newsletter Available online at: https://www.mangrovesforthefuture. org/assets/Repository/Documents/MFF-newsletter-number-18-Nov-Dec2010.pdf

Nguyen, H.-H., McAlpine, C., Pullar, D., Johansen, K., and Duke, N. C. (2013). The relationship of spatial-temporal changes in fringe mangrove extent and adjacent land-use: Case study of Kien Giang coast, Vietnam. Ocean Coast. Manag. 76, 12-22. doi: 10.1016/j.ocecoaman.2013. 01.003

Pang, W., Dai, Z., Ma, B., Wang, J., Huang, H., and Li, S. (2020). Linkage between turbulent kinetic energy, waves and suspended sediment concentrations in the nearshore zone. Marine Geology. 425, 106190. doi: 10.1016/j.margeo.2020.106190
Reeve, D., Chadwick, A., and Fleming, C. (2004). Coastal Engineering: Processes, Theory and Design Practice, 1st Edn. CRC Press, 496. doi: 10.4324/9780203647356

Schmitt, K., T., Albers, T. T., and Pham, and, S. C., Dinh (2013). Sitespecific and integrated adaptation to climate change in the coastal mangrove zone of Soc Trang Province. Viet Nam. J. Coast Conserv. 17, 545-558. doi: 10.1007/s11852-013-0253-4

Schoonees, T., Gijón Mancheño, A., Scheres, B., Bouma, T. J., Silva, R., Schlurmann, T., et al. (2019). Hard Structures for Coastal Protection, Towards Greener Designs. Estuaries and Coasts. 42, 1709-1729. doi: 10.1007/s12237-019-00551-z

SIWRR (2019). Coastal Protection Status Assessment in the Mekong Delta (in Vietnamese).

U. S. Army Corps of Engineers (1992). Coastal groins and nearshore breakwaters. Engineering Manual. Report EM1110-2-1617.

Van Rijn, L. C. (2013). Design of hard coastal structures against erosion. Available online at: http://www.leovanrijn-sediment.com

Wetland International (2014). Building with Nature Indonesia - reaching scale for coastal resilience. Available online at: www.wetlands.org/

Conflict of Interest: The authors declare that the research was conducted in the absence of any commercial or financial relationships that could be construed as a potential conflict of interest.

Publisher's Note: All claims expressed in this article are solely those of the authors and do not necessarily represent those of their affiliated organizations, or those of the publisher, the editors and the reviewers. Any product that may be evaluated in this article, or claim that may be made by its manufacturer, is not guaranteed or endorsed by the publisher.

Copyright (c) 2021 Mai Van, Ngo, Mai and Dao. This is an open-access article distributed under the terms of the Creative Commons Attribution License (CC BY). The use, distribution or reproduction in other forums is permitted, provided the original author(s) and the copyright owner(s) are credited and that the original publication in this journal is cited, in accordance with accepted academic practice. No use, distribution or reproduction is permitted which does not comply with these terms. 